\title{
Ameliorative potential of Ocimum sanctum in chronic constriction injury-induced neuropathic pain in rats
}

\author{
GURPREET KAUR, ANJANA BALI, NIRMAL SINGH and AMTESHWAR S. JAGGI
}

Department of Pharmaceutical Sciences and Drug Research, Punjabi University, Patiala-147002, Punjab, India

Manuscript received on January 1, 2013; accepted for publication on February 18, 2013

\begin{abstract}
The present study was designed to investigate the ameliorative potential of Ocimum sanctum and its saponin rich fraction in chronic constriction injury-induced neuropathic pain in rats. The chronic constriction injury was induced by placing four loose ligatures around the sciatic nerve, proximal to its trifurcation. The mechanical hyperalgesia, cold allodynia, paw heat hyperalgesia and cold tail hyperalgesia were assessed by performing the pinprick, acetone, hot plate and cold tail immersion tests, respectively. Biochemically, the tissue thio-barbituric acid reactive species, super-oxide anion content (markers of oxidative stress) and total calcium levels were measured. Chronic constriction injury was associated with the development of mechanical hyperalgesia, cold allodynia, heat and cold hyperalgesia along with an increase in oxidative stress and calcium levels. However, administration of Ocimum sanctum (100 and $200 \mathrm{mg} / \mathrm{kg}$ p.o.) and its saponin rich fraction (100 and $200 \mathrm{mg} / \mathrm{kg}$ p.o.) for 14 days significantly attenuated chronic constriction injury-induced neuropathic pain as well as decrease the oxidative stress and calcium levels. It may be concluded that saponin rich fraction of Ocimum sanctum has ameliorative potential in attenuating painful neuropathic state, which may be attributed to a decrease in oxidative stress and calcium levels.
\end{abstract}

Key words: chronic constriction injury, Ocimum sanctum, Saponin rich fraction, calcium, oxidative stress.

\section{INTRODUCTION}

The International Association for the Study of Pain defines neuropathic pain as "initiated or caused by a primary lesion or dysfunction in the nervous system" and defines neuropathic due to disordered peripheral or central nerves (Merskey et al. 1994). Neuropathic pain is not a single entity; it is a heterogeneous group of conditions that differs in not only aetiology, but also in location (Woolf and Mannion 1999), and symptoms respect neither cause nor anatomical site. Neuropathic pain is generally characterized by sensory

Correspondence to: Amteshwar Singh Jaggi

E-mail: amteshwarjaggi@yahoo.co.in abnormalities such as unpleasant abnormal sensation (dysesthesia), an increased response to painful stimuli (hyperalgesia), and pain in response to a stimulus that does not normally provoke pain (allodynia) (Woolf and Mannion 1999, Jaggi and Singh 2011).

Chronic constriction injury is a novel model of peripheral neuropathy as the alterations produced in this model of peripheral neuropathy are analogous to the human beings and the symptoms in this rat model are parallel to causalgia or complex regional pain syndrome (Bennett and Xie 1988). Chronic constriction injury produces unilateral peripheral neuropathy due to compression of the sciatic nerve 
and hence, it has been extensively used in research for the analysis of sensory abnormalities associated with entrapment neuropathy (Nakamura and Atsuta 2006). Furthermore, the behavioral changes observed in this model are the most sustained and generalized ones with regards to other models of peripheral neuropathy (Dowdall et al. 2005).

Ocimum sanctum (L.), also known as tulsi is an aromatic plant in the family Lamiaceae which has a number of medicinal and non-medicinal organic compounds (oleanolic acid, ursolic acid, rosmarinic acid, eugenol, carvacrol, linalool, - caryophyllene - elemene and germacrene) (Ahmad et al. 2012, Venuprasad et al. 2013). All the parts of the Ocimum sanctum plant like fresh leaves, juice, seeds and volatile oil are very beneficial to the health of humans. It possesses diverse protective effects including hepato-protective, immuno-modulatory, anti-ulcer, anti-diabetic, anti-hypercholesterolaemic, nerve tonic, chemo-protective, nootropic, antitussive, antiinflammatory, wound healing, anti-tumorigenesis, anti-convulsant, anthelmintic, anti-bacterial, antianxiety, and anti-stress activities (Jaggi et al. 2003, Yanpallewar et al. 2004, de Almeida et al. 2007, Bhattacharyya etal. 2008, Baliga et al.2013). Recently, our laboratory documented that Ocimum sanctum has ameliorative potential in attenuating sciatic nerve transection and vincristine-induced neuropathic pain (Muthuraman et al. 2008b, Kaur et al. 2010).

Saponins are important phyto-constituents present in different plants including Ocimum sanctum in which these constitute an important chemical class and include pentacyclic triterpenoids saponins such as ursolic acid, oleanoloc acid. A number of studies have shown that saponins exert diverse biological actions such as anti-hypertensive (Rhiouani et al. 1999), anti-cancer (Shibata 2001), anti-convulsant (Pal et al. 2005), anti-diabetic (Chen et al. 2008), antiamnestic (Wang et al. 2006), hypocholesterolaemic (Al-Habori and Raman 1998) and neuroprotective (Kim et al. 2005). Furthermore, saponins have also been shown to exhibit anti-nociceptive actions
(Moharram et al. 2007, Wang et al. 2008); alleviate neuropathic pain in long standing diabetes (Yin et al. 2004) and nerve entrapment induced facial paralysis (Bell's palsy) (Liu et al. 2008).

Therefore, the present study was designed to investigate the ameliorative role of Ocimum sanctum in another model of neuropathic pain i.e. chronic constriction-induced neuropathy and to further explore the contributory role of saponins in Ocimum sanctum mediated beneficial effect in neuropathic pain.

\section{MATERIALS AND METHODS}

\section{EXPERIMENTAL ANIMALS}

Wistar albino rats weighing 180-250 g, maintained on standard laboratory diet (Kisan Feeds Ltd., Mumbai, India) and having free access to tap water were employed in the present study. They were housed in the departmental animal house and were exposed to normal cycle of light and dark. The experimental protocol was approved by the Institutional Animal Ethics Committee (IAEC) and the care of the animals was carried out as per the guidelines of the Committee for the Purpose of Control and Supervision of Experiments on Animals (CPCSEA), Ministry of Environment and Forest, Government of India (Reg. No.- 107/ 1999/ CPCSEA).

INDUCTION OF NEUROPATHIC PAIN BY CHRONIC

\section{CONSTRICTION INJURY}

Peripheral neuropathic pain was induced in rats by chronic constriction injury (CCI) (Bennett and Xie 1988, Muthuraman et al. 2008a). In brief, rats were deeply anesthetized with thiopental sodium (35 mg/kg i.p.). The hair of the rat's lower back and thigh were shaved, and the skin was sterilized with $0.5 \%$ chlorhexidine. The skin of the lateral surface of the left thigh was incised and a cut was made directly through the biceps femoris muscle to expose the sciatic nerve, and four ligatures (silk 4-0) were placed around the nerve proximal part of the trifurcation with an approximate distance of one 
millimeter between each ligature. The ligatures were loosely tied until a short flick of the ipsilateral hind limb was observed. After performing nerve ligation, muscular and skin layer were immediately sutured with thread, and topical antibiotic was applied. Due to the distinct development of postural defects in the paw of chronic constriction injury control animals, the behavioral studies could not be blinded for comparing normal control; sham control and chronic constriction injury control groups. However, for all other groups the behavioral tests were blinded.

\section{Plant MATERIAL}

Fresh leaves of Ocimum sanctum were collected from Patiala and authenticated by Botany Department, Punjabi University, Patiala. The Plant sample has been kept in Voucher specimen (PUP039/2008-2009) at Punjabi university, Patiala. The fresh leaves of Ocimum sanctum were shed dried at room temperature and reduced to coarse powder. The powder was extracted with mixture of methanol: water (3:1). The solvent was completely removed at $50^{\circ} \mathrm{C}$ under reduced pressure. The yield of the extract was $13 \%(\mathrm{w} / \mathrm{w})$ in terms of dried starting material. The saponin rich fraction was extracted from the concentrated hydro-alcoholic extract as described earlier (Ebata et al. 1996, Sadraei et al. 2003). The yield of saponin fraction was $6.8 \%$ $(w / w)$. Briefly, the hydro-alcoholic extract was decanted by $n$-hexane followed by extraction with n-butanol. The butanol was completely removed at $50^{\circ} \mathrm{C}$ under reduced pressure (Table I).

\section{BEHAVIORAL EXAMINATION}

\section{Paw Cold-Allodynia (Acetone Drop Test)}

The cold allodynia was assessed by spraying a $100 \mu \mathrm{L}$ of acetone onto the planter surface of the paw, without touching the skin. The duration of withdrawal response was recorded with an arbitrary minimum value of $0.5 \mathrm{~s}$ and a maximum value of $20 \mathrm{~s}$ (Decosterd et al. 2000).
TABLE I

HPTLC fingerprinting profile of hydro-alcoholic extract of Ocimum sanctum taking chloroform and methanol (80:20) as mobile phase and using anisaldehyde as spraying agent. The values indicate the $R_{f}$ of the separated bands.

\begin{tabular}{c|c|c|c}
\hline $\begin{array}{c}\text { S. No of } \\
\text { Resolving } \\
\text { Bands }\end{array}$ & UV 254 nm & UV 366 & $\begin{array}{c}\text { Under white } \\
\text { light }\end{array}$ \\
\hline 1. & - & - & 0.44 \\
\hline 2. & - & - & 0.60 \\
\hline 3. & - & - & 0.71 \\
\hline 4. & - & - & 0.78 \\
\hline 5. & - & - & 0.85 \\
\hline
\end{tabular}

\section{Paw Heat-Hyperalgesia (Hot Plate Test)}

The thermal nociceptive threshold, as an index of thermal hyperalgesia, was assessed by the Eddy's hot plate, which is an instrument designed by Eddy and Leimbach (1953) to assess thermal sensitivity. The plate was pre-heated and maintained at a temperature of $52.5 \pm 2.0^{\circ} \mathrm{C}$. The rat was placed on the hot plate and nociceptive threshold, with regards to licking of the hind paw, was recorded in seconds. The cut-off time of $20 \mathrm{~s}$ was maintained (Jain et al. 2009).

\section{Mechanical hyperalgesia: (Pin prick test)}

The mechanical hyperalgesia was assessed by the pinprick test as described by Erichsen and Blackburn-Munro (Erichsen et al. 2002). The surface of the injured hind paw was touched with the point of the bent gauge needle (at $90^{\circ}$ to the syringe) at an intensity sufficient to produce a reflex withdrawal response in normal non-operated animals, but at an intensity which was insufficient to penetrate the skin. The duration of the paw withdrawal was recorded in seconds with a stopwatch. A cut-off time of $20 \mathrm{~s}$ was maintained. The duration of withdrawal response was recorded with an arbitrary minimum value of $0.5 \mathrm{~s}$ and a maximum value of $20 \mathrm{~s}$.

The contra-lateral paw was not used to compare the hypersensitivity changes with the injured ipsilateral paw because there have been reports suggesting the hypersensitivity changes in the contralateral paw 
on subjecting the animal to the unilateral nerve injury (Arguis et al. 2008). Furthermore, the contralateral pain development has also been reported in human beings (Koltzenburg et al. 1999).

\section{Tail Cold-Hyperalgesia Test (Tail Immersion Test)}

In peripheral nerve injury, initial burst from peripheral site and later sustained activation of peripheral nociceptors leads to a central sensitization of the dorsal horn neurons in the spinal cord. This central sensitization is an important feature in inducing long-term thermal allodynia and hyperalgesia, which may be assessed by noting down the changes in thermal sensitivity in the tail (Mika et al. 2008, 2009, Muthuraman et al. 2008a). The tail cold-hyperalgesia was noted by immersing a terminal part of the tail $(1 \mathrm{~cm})$ in the water, maintained at a temperature of $0-4^{\circ} \mathrm{C}$. The tail withdrawal latency was recorded and a cut-off time of $20 \mathrm{~s}$ was maintained (Necker et al. 1978).

BIOCHEMICAL PARAMETERS

All the groups of animals were sacrificed after the $14^{\text {th }}$ day by cervical dislocation and the sciatic nerve was isolated immediately. The uniformity among the different nerve samples were maintained by taking the constant weight of the respective samples. The excised sciatic nerve homogenate $(10 \% \mathrm{w} / \mathrm{v})$ was prepared with $0.1 \mathrm{M}$ Tris $\mathrm{HCl}$ buffer $(\mathrm{pH}$ 7.4). The tubes with homogenate were kept in ice water for 30 minutes and centrifuged at $4{ }^{\circ} \mathrm{C}(2500$ $\mathrm{rpm}, 10 \mathrm{~min})$. The supernatant of homogenate was separated, and employed to estimate total protein content, TBARS, superoxide anion concenteration and total calcium content.

\section{Estimation of the protein content}

The protein concentration in the sciatic nerve was estimated according to the method of Lowry et al. (1951). using bovine serum albumin as a standard. The absorbance was determined spectrophotometrically at $750 \mathrm{~nm}$.
Estimation of thio-barbituric acid reactive substances

The estimation of lipid peroxidation in the sciatic nerve was done by measuring the thiobarbituric acid reactive substances by the method of Okhawa et al. (1979). The absorbance was measured spectrophotometrically at $532 \mathrm{~nm}$. The concentration was expressed in terms of nmol of thio-barbituric acid reactive substances/mg protein.

\section{Estimation of superoxide anion generation}

The superoxide anion generation in the sciatic nerve was estimated in terms of measuring reduced nitroblue tetrazolium (NBT) (Wang et al. 1998). The absorbance of formazan was determined spectrophotometerically at $540 \mathrm{~nm}$.

\section{Estimation of total calcium}

The total calcium levels were estimated in the sciatic nerve as described earlier (Severinghaus and Ferrebee 1950, Muthuraman et al. 2008a, b). Briefly, the sciatic nerve homogenate was mixed with $1 \mathrm{ml}$ of trichloroacetic acid (4\%) in ice cold conditions and centrifuged at $1500 \mathrm{~g}$, for 10 minutes. The clear supernatant was used for the estimation of total calcium ion by atomic emission spectroscopy at $556 \mathrm{~nm}$.

\section{EXPERIMENTAL PROTOCOL}

Ten groups, each group comprising six wistar albino rats, were employed in the present study.

Group I: Normal control group

Rats were not subjected to any surgical procedure and were kept for 14 days. The behavioral tests were employed on different days i.e., day $2^{\text {nd }}, 4^{\text {th }}, 6^{\text {th }}, 8^{\text {th }}$, $11^{\text {th }}$ and $14^{\text {th }}$. All the animals were sacrificed at end of the $14^{\text {th }}$ day and the biochemical analysis was done for estimation of protein content, TBARS, superoxide anion and total calcium.

Group II: Sham control group

Rats were subjected to surgical procedure to expose the left sciatic nerve, on day one, without any nerve 
ligation. The behavioral tests were employed after surgery on different days as described in group I and the biochemical analysis was done at the end of the $14^{\text {th }}$ day as described in group I.

Group III: CCI control group

Rats were subjected to surgical procedure to expose and ligate the left sciatic nerve as described earlier. The behavioral tests and the biochemical parameters were assessed as described in group I.

\section{Group IV: Vehicle in CCI group}

After subjecting the rats to CCI, carboxymethylcellulose suspension $(0.5 \% \mathrm{w} / \mathrm{v}$, p.o. $)$ was administered for 14 consecutive days, starting from day one just prior to surgery. The behavioral tests and the biochemical parameters were assessed as described in group I.

Group V: Hydro-alcoholic extract of Ocimum sanctum per se

The hydro-alcoholic extract of Ocimum sanctum (200 mg/kg p.o.) was administered to normal rats for 14 consecutive days, starting from day one prior to surgery. The behavioral tests and the biochemical parameters were assessed as described in group I.

Group VI: Saponin rich extract of Ocimum sanctum per se

The saponin rich extract of Ocimum sanctum (200 mg/kg p.o.) was administered to normal rats for 14 consecutive days, starting from day one prior to surgery. The behavioral tests and the biochemical parameters were assessed as described in group I.

Group VII and VIII: Hydro-alcoholic extract of Ocimum sanctum $(100 ; 200 \mathrm{mg} / \mathrm{kg}$ p.o.) in CCI group

The hydro-alcoholic extract of Ocimum sanctum (100; $200 \mathrm{mg} / \mathrm{kg}$ p.o.) was administered for 14 consecutive days, starting from day one just prior to surgery. The behavioral tests and the biochemical parameters were assessed as described in group I.
Group IX and X: Saponin rich fraction of Ocimum sanctum $(100 ; 200 \mathrm{mg} / \mathrm{kg}$ p.o.) in CCI group

The saponin rich fraction of Ocimum sanctum (100 and $200 \mathrm{mg} / \mathrm{kg}$ p.o.) was administered for 14 consecutive days, starting from day one just prior to surgery. The behavioral tests and the biochemical parameters were assessed as described in group I.

\section{STATISTICAL ANALYSIS}

All the results were expressed as mean \pm S.E.M. The data of behavioral results were statistically analyzed by two-way ANOVA followed by Bonferonni's post hoc test by using Graph pad prism Version-5.0 software. The data of biochemical results were statistically analyzed by one-way ANOVA followed by Tukey's multiple range test by using Sigmastat Version-2.0 software. The $p$-value $<0.05$ was considered to be statistically significant.

\section{RESULTS}

EFFECT OF Ocimum sanctum AND ITS SAPONIN RICH FRACTION ON COLD ALLODYNIA

The chronic constriction injury of the sciatic nerve resulted in the development of cold allodynia as reflected by an increase in the duration of hind paw withdrawal, when compared to normal control group. However, administration of Ocimum sanctum (100 and $200 \mathrm{mg} / \mathrm{kg}$ p.o.) and its saponin rich fraction (100 and $200 \mathrm{mg} / \mathrm{kg}$ p.o.) significantly attenuated the chronic constriction injury-induced increase in withdrawal duration of the hind paw in response to non-noxious cold stimuli. The effect of saponin rich fraction in attenuating cold allodynia was significantly higher than the hydro-alcoholic extract at the same dose levels. Vehicle administration did not modulate chronic constriction injury-induced alterations in behavior in response to non-noxious cold stimulus. Per se administration of Ocimum sanctum and its saponin rich fraction also did not produce alterations in the normal rats (Figure 1). 


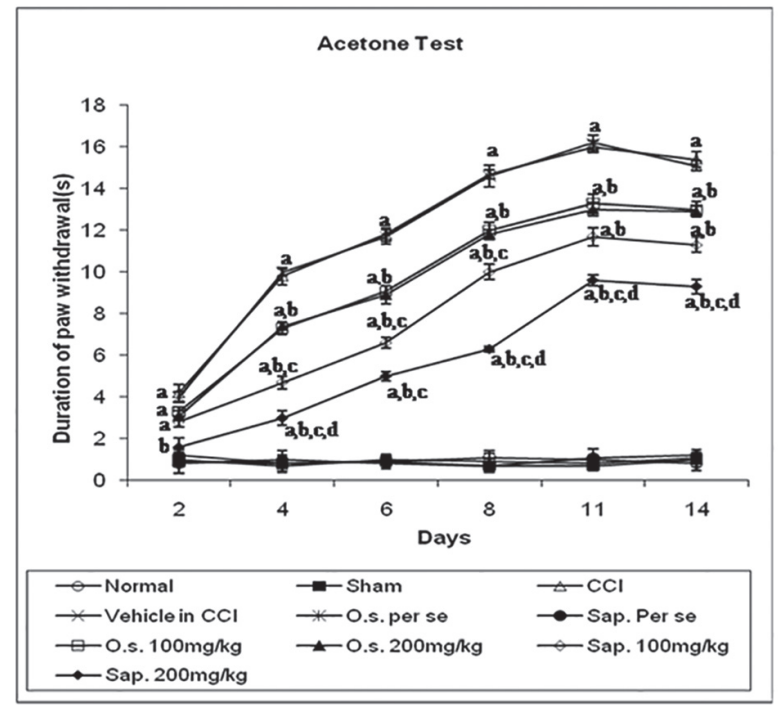

Figure 1 - Effect of Ocimum sanctum and its saponin rich fraction on cold allodynia in chronic constriction injury-induced neuropathic pain. CCI: chronic constriction injury; O.s.: Ocimum sanctum; Sap.: saponin rich extract of Ocimum sanctum. Data were expressed as mean \pm S.E.M., $n=6$ rats per group. $a=p<0.05$ Vs normal control group, $b=p<0.05 \mathrm{Vs}$ CCI control group, $\mathrm{c}=\mathrm{p}<0.05 \mathrm{Vs}$ Ocimum sanctum 100 and $200 \mathrm{mg} / \mathrm{kg}$ group, $\mathrm{d}=\mathrm{p}<0.05 \mathrm{Vs}$ saponin rich fraction $100 \mathrm{mg} / \mathrm{kg}$ group.

\section{EFFECT OF Ocimum sanctum AND ITS SAPONIN RICH}

\section{FRACTION ON MECHANICAL HYPERALGESIA}

The chronic constriction was associated with the development of mechanical hyperalgesia as reflected by an increase in the hind paw withdrawal duration, when compared to normal control group. However, administration of Ocimum sanctum (100 and $200 \mathrm{mg} /$ $\mathrm{kg}$ p.o.) and its saponin rich fraction (100 and $200 \mathrm{mg} /$ $\mathrm{kg}$ p.o.) significantly attenuated chronic constriction injury-induced increase in withdrawal duration of the hind paw in response to noxious mechanical stimuli. The effect of saponin rich fraction in attenuating mechanical hyperalgesia was significantly higher than the hydro-alcoholic extract at the same dose levels. Vehicle administration did not modulate chronic constriction injury-induced alteration in behavior in response to noxious mechanical stimulus. Per se administration of Ocimum sanctum and its saponin rich fraction also did not produce alterations in the normal rats (Figure 2).

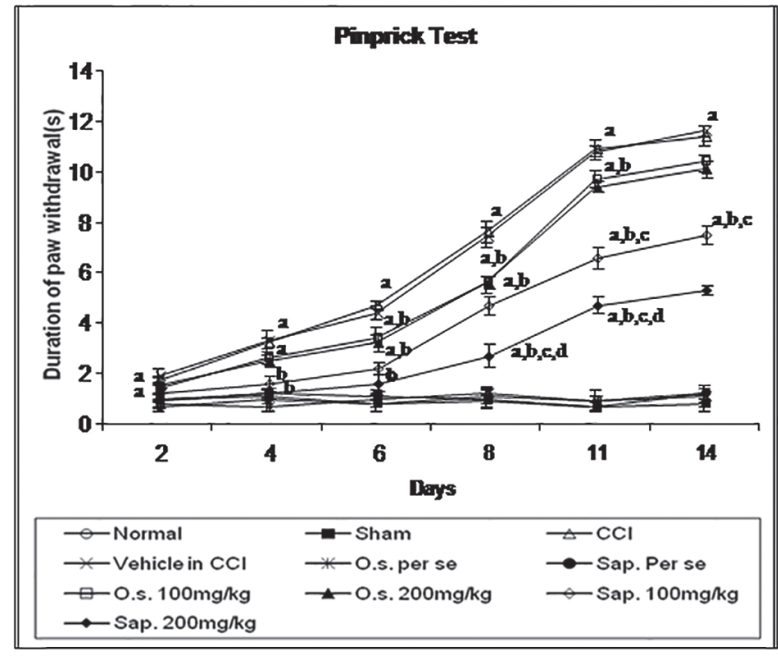

Figure 2 - Effect of Ocimum sanctum and its saponin rich fraction on mechanical hyperalgesia in chronic constriction injuryinduced neuropathic pain. CCI: chronic constriction injury, O.s.: Ocimum sanctum, Sap.: saponin rich extract of Ocimum sanctum. Data were expressed as mean \pm S.E.M., $n=6$ rats per group. $\mathrm{a}=$ $\mathrm{p}<0.05$ Vs normal control group, $\mathrm{b}=\mathrm{p}<0.05 \mathrm{Vs}$ CCI control group, $\mathrm{c}=\mathrm{p}<0.05 \mathrm{Vs}$ Ocimum sanctum 100 and $200 \mathrm{mg} / \mathrm{kg}$ group, $\mathrm{d}=\mathrm{p}<0.05 \mathrm{Vs}$ saponin rich fraction $100 \mathrm{mg} / \mathrm{kg}$ group.

EFFECT OF Ocimum sanctum AND ITS SAPONIN RICH FRACTION ON PAW HEAT AND TAIL COLD HYPERALGESIA

The chronic constriction injury led to the development of paw heat and tail cold hyperalgesia as reflected by decrease in the threshold withdrawal latency of hind paw and tail respectively, when compared to normal control group. However, administration of Ocimum sanctum (100 and $200 \mathrm{mg} / \mathrm{kg}$ p.o.) and its saponin rich fraction (100 and $200 \mathrm{mg} / \mathrm{kg}$ p.o.) significantly attenuated the chronic constriction injury-induced decrease in the withdrawal latency in response to noxious thermal stimuli. The effect of saponin rich fraction in attenuating thermal hyperalgesia was significantly higher than the hydro-alcoholic extract at the same dose levels. Vehicle administration did not modulate chronic constriction injury-induced alteration in behavior in response to noxious thermal stimulus. Per se administration of Ocimum sanctum and its saponin rich fraction also did not produce alterations in the normal rats (Figures 3 and 4). 


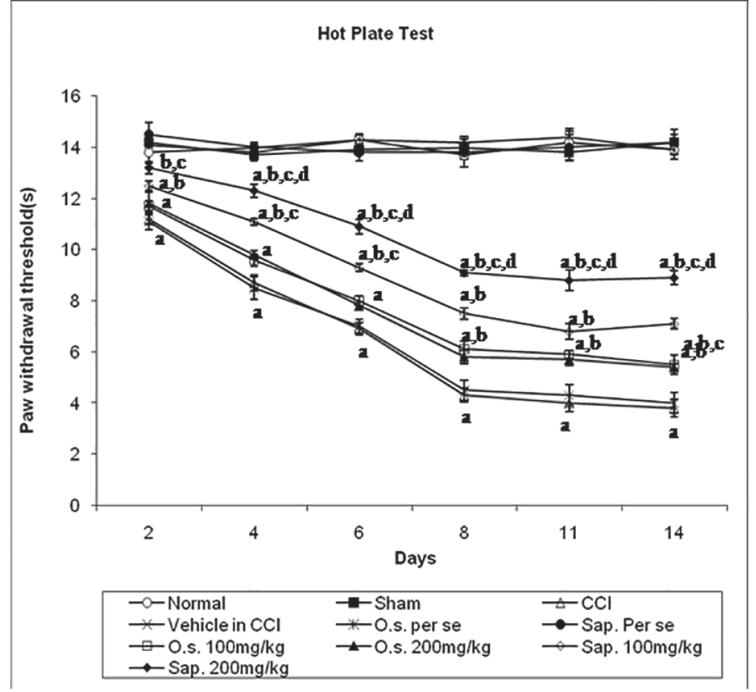

Figure 3 - Effect of Ocimum sanctum and its saponin rich fraction on paw heat hyperalgesia in chronic constriction injury-induced neuropathic pain. Data were expressed as mean \pm S.E.M., $n=6$ rats per group. CCI: chronic constriction injury, O.s.: Ocimum sanctum, Sap.: saponin rich extract of Ocimum sanctum. $\mathrm{a}=\mathrm{p}<0.05 \mathrm{Vs}$ normal control group, $\mathrm{b}=\mathrm{p}<0.05 \mathrm{Vs} \mathrm{CCI}$ control group, $\mathrm{c}=\mathrm{p}<0.05 \mathrm{Vs}$ Ocimum sanctum 100 and $200 \mathrm{mg} /$ $\mathrm{kg}$ group, $\mathrm{d}=\mathrm{p}<0.05 \mathrm{Vs}$ saponin rich fraction $100 \mathrm{mg} / \mathrm{kg}$ group.

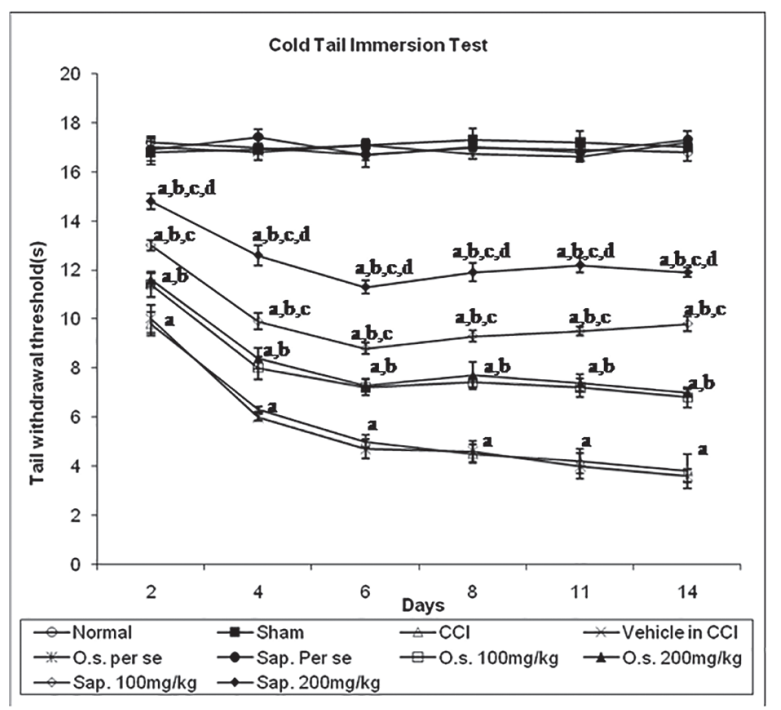

Figure 4 - Effect of Ocimum sanctum and its saponin rich fraction on tail cold hyperalgesia in chronic constriction injuryinduced neuropathic pain. Data were expressed as mean \pm S.E.M., $\mathrm{n}=6$ rats per group. CCI: chronic constriction injury, O.s.: Ocimum sanctum, Sap.: saponin rich extract of Ocimum sanctum. $\mathrm{a}=\mathrm{p}<0.05 \mathrm{Vs}$ normal control group, $\mathrm{b}=\mathrm{p}<0.05 \mathrm{Vs} \mathrm{CCI}$ control group, $c=p<0.05 \mathrm{Vs}$ Ocimum sanctum 100 and $200 \mathrm{mg} /$ $\mathrm{kg}$ group, $\mathrm{d}=\mathrm{p}<0.05 \mathrm{Vs}$ saponin rich fraction $100 \mathrm{mg} / \mathrm{kg}$ group.
EFFECT OF Ocimum sanctum AND ITS SAPONIN RICH

FRACTION ON OXIDATIVE STRESS MARKERS AND TOTAL

\section{CALCIUM CONTENT}

The chronic constriction injury resulted in an increase in the oxidative stress markers and total calcium content as reflected by an increase in the tissue thio-barbituric acid reactive substances, superoxide anion content and total calcium levels, when compared to normal control group. However, administration of Ocimum sanctum (100 and 200 $\mathrm{mg} / \mathrm{kg}$ p.o.) and its saponin rich fraction (100 and $200 \mathrm{mg} / \mathrm{kg}$ p.o.) significantly attenuated the chronic constriction injury-induced increase in oxidative stress markers and total calcium levels. The effect of saponin rich fraction in attenuating the rise in the levels of oxidative stress markers and the calcium levels was significantly higher than the hydro-alcoholic extract at the same dose levels. Vehicle administration did not modulate chronic constriction injury-induced alteration in oxidative stress markers and total calcium content. Per se administration of Ocimum sanctum and its saponin rich fraction also did not produce any biochemical alterations in the normal rats (Table II).

\section{DISCUSSION}

In the present study, chronic constriction injury led to significant development of cold allodynia, mechanical, tail cold and paw heat hyperalgesia. These behavioral changes were evident from the $2^{\text {nd }}$ day of surgery and were at peak after 12-14 days of surgery. The chronic constriction injury model has been characterized by significant development of mechanical hyperalgesia, cold allodynia, mechanical allodynia, thermal hyperalgesia and thermal allodynia, and these behavioral alterations are much more significant in this model as compared to other models (Dowdall et al. 2005, Jaggi et al. 2011). Ligation of the sciatic nerve produces compression leading to mechanical injury of capillary endothelial cells and epineural edema, which subsequently exacerbates the nerve 
TABLE II

Effect of Ocimum sanctum and its saponin rich fraction on thio-barbituric acid reactive subatances, superoxide anion content and total calcium. CCI: chronic constriction injury, O.s.: Ocimum sanctum, Sap.: saponin rich fraction of Ocimum sanctum. Data were expressed as mean \pm S.E.M., $n=6$ rats per group. $\mathbf{a}=p<0.05$ Vs sham control group, $\mathbf{b}=p<0.05$ Vs CCI control group, $\mathbf{c}=p<0.05$ Vs Ocimum sanctum 100 and $200 \mathrm{mg} / \mathrm{kg}$ group, $d=p<0.05 \mathrm{Vs}$ saponin rich fraction $100 \mathrm{mg} / \mathrm{kg}$ group.

\begin{tabular}{c|c|c|c|c}
\hline Groups & $\begin{array}{c}\text { Total Protein } \\
(\mathrm{mg} / \mathrm{ml})\end{array}$ & $\begin{array}{c}\text { TBARS } \\
(\mathrm{nmol} / \mathrm{mg} \text { of protein })\end{array}$ & $\begin{array}{c}\text { Superoxide Anion } \\
\text { Content } \\
(\mathrm{pmol} / \mathrm{min} / \mathrm{mg})\end{array}$ & $\begin{array}{c}\text { Total Calcium } \\
(\mathrm{ppm} / \mathrm{mg} \text { of protein) }\end{array}$ \\
\hline Normal Control & $5.17 \pm 0.23$ & $5.97 \pm 0.26$ & $0.15 \pm 0.02$ & $4.97 \pm 0.21$ \\
\hline Sham Control & $5.23 \pm 0.21$ & $6.01 \pm 0.23$ & $0.17 \pm 0.01$ & $5.10 \pm 0.24$ \\
\hline CCI Control & $5.36 \pm 0.13$ & $8.90 \pm 0.24^{\mathrm{a}}$ & $0.91 \pm 0.05^{\mathrm{a}}$ & $41.21 \pm 0.17^{\mathrm{a}}$ \\
\hline Vehicle in CCI & $5.29 \pm 0.17$ & $8.93 \pm 0.22^{\mathrm{a}}$ & $0.93 \pm 0.04^{\mathrm{a}}$ & $40.0 \pm 00.22^{\mathrm{a}}$ \\
\hline O.s. $p e r$ se & $5.21 \pm 0.15$ & $6.00 \pm 0.24$ & $0.12 \pm 0.01$ & $5.09 \pm 0.15$ \\
\hline Sap. $p e r$ se & $5.30 \pm 0.14$ & $6.06 \pm 0.21$ & $0.14 \pm 0.02$ & $4.92 \pm 0.17$ \\
\hline O.s. $100 \mathrm{mg} / \mathrm{kg}$ & $5.33 \pm 0.22$ & $8.13 \pm 0.14^{\mathrm{a}, \mathrm{b}}$ & $0.67 \pm 0.03^{\mathrm{a}, \mathrm{b}}$ & $25.21 \pm 0.20^{\mathrm{a}, \mathrm{b}}$ \\
\hline O.s. $200 \mathrm{mg} / \mathrm{kg}$ & $5.26 \pm 0.16$ & $8.06 \pm 0.17^{\mathrm{a}, \mathrm{b}}$ & $0.69 \pm 0.03^{\mathrm{a}, \mathrm{b}}$ & $25.47 \pm 0.14^{\mathrm{a}, \mathrm{b}}$ \\
\hline Sap. $100 \mathrm{mg} / \mathrm{kg}$ & $5.35 \pm 0.13$ & $7.20 \pm 0.21^{\mathrm{a}, \mathrm{b}, \mathrm{c}}$ & $0.41 \pm 0.03^{\mathrm{a}, \mathrm{b}, \mathrm{c}}$ & $19.71 \pm 0.19^{\mathrm{a}, \mathrm{b}, \mathrm{c}}$ \\
\hline Sap. $200 \mathrm{mg} / \mathrm{kg}$ & $5.29 \pm 0.14$ & $6.40 \pm 0.23^{\mathrm{a}, \mathrm{b}, \mathrm{c}, \mathrm{d}}$ & $0.28 \pm 0.02^{\mathrm{a}, \mathrm{b}, \mathrm{c}, \mathrm{d}}$ & $12.52 \pm 0.21^{\mathrm{a}, \mathrm{b}, \mathrm{c}, \mathrm{d}}$ \\
\hline
\end{tabular}

compression. Furthermore, the material used to ligate sutures also initiates immune reaction and hence, invasion by immune cells along with the production of immune modulators contribute significantly in inducing the pain behavior (Kleinschnitz et al. 2006, Morin et al. 2007).

The precise details of initiation and maintenance of hyper-responsiveness of injured paw to noxious as well as non-noxious stimuli are not clear. However, it has been documented that following the loose ligation mediated nerve injury, the nerve segment distal to ligature comprises of both injured as well as non-injured intact nerve fibers. Within the nerve segment, the injured nerve fibers trigger incompletely understood biochemical changes, which alter the chemical milieu of the non-injured nerve fibers and thus eventually result in significant changes in the responsiveness of noninjured nerves with respect to noxious and nonnoxious stimuli (Klusáková and Dubový 2009).

In the present study, pre-treatment with hydroalcoholic extract of Ocimum sanctum significantly attenuated the chronic constriction injury-induced behavioral alterations in neuropathic pain, thus suggesting its potential in ameliorating the painful state of neuropathy. In chronic constriction injury model, the nerve trauma is associated with an initial discharge that results in the development of neuroma and sustained behavioral alterations. There have been reports suggesting that pre-emptive treatment with drugs minimizes the initial discharge and thus, help alleviate the neuropathic manifestations (Sotgiu et al. 1994, Mika et al. 2007). Therefore, in the present study, the treatment was given prior to surgery to prevent injury discharge. Traditionally, Ocimum sanctum has been used as a nerve tonic to alleviate disorders related to nerves. In our previous studies, the hydroalcohlic extract of Ocimum sanctum was shown to attenuate neuropathic pain in axotomy model i.e., sciatic nerve transection model (Muthuraman et al. 2008b). In another study, the saponin rich fraction was shown to produce beneficial effects in chemotherapeutic agentinduced neuropathy in a vincristine model (Kaur et al. 2010). This present study is the extension of our previous studies to evaluate the neuropathic pain attenuating effects of Ocimum sanctum in chronic constriction-induced neuropathy. 
Ocimum sanctum is a rich source of a number of saponins and the most important of them are ursolic acid and oleanolic acid. These saponins have been reported to possess beneficial effects in a number of disorders such as amnesia ( $\mathrm{Lu}$ et al. 2007), hypertension (Somova et al. 2003), myocardial ischemia (Senthil et al. 2007), and cancer (Manu et al.2008). Furthermore, the saponins have also shown to be beneficial effects in relieving nociceptive pain (Moharram et al. 2007, Wang et al. 2008) as well as neuropathic pain in diabetes (Yin et al. 2004) and facial paralysis (Bell's palsy) due to nerve entrapment (Liu et al. 2008). Therefore, to explore the chemical class of Ocimum sanctum responsible for its beneficial effect, its saponin rich fraction was evaluated in neuropathic pain. In the present investigation, pre-treatment with the saponin rich fraction of Ocimum sanctum also attenuated chronic constriction injury-induced behavioral alterations in neuropathic pain. Therefore, it may be proposed that saponins are the main components responsible for the noted beneficial effects of Ocimum sanctum in neuropathic pain.

In the present study, the same doses of hydroalcohlic and saponin rich fraction were collected to compare their relative potency of neuropathic pain attenuation. At the same dose the saponin rich fraction exhibited greater potency in attenuating neuropathic pain as compared to corresponding hydroalcohlic extracts. The difference in the potency of two fractions could have also been evaluated by comparing the doses at which the comparable effects were produced. However, the authors selected the former method to evaluate the difference in potency by comparing the effects at the same dose levels. The major limitation of comparing the dose at which same effects are produce is requirement of more number of groups in selecting the dose of saponin rich fraction which corresponds to hydroalcohlic extracts. However, due to animal ethic constraint, the number of animals and groups could not exceed certain limits.
Furthermore, in this study chronic constriction injury was associated with the rise in the oxidative stress (rise in thio-barbituric acid reactive substances and superoxide anion content) and total calcium content. These results are in line with earlier reports suggesting the key role of oxidative stress in chronic constriction injury (Tan et al. 2009, Zeinab and Bereha 2001, Muthuraman et al. 2008a). In the chronic constriction injury model of rat neuropathic pain, heat hyperalgesia was reduced by systemically injected antioxidants (Kim et al. 2004, Khalil et al. 1999). Calcium accumulation has been well documented to play an important role in chronic constriction injury-induced neuropathy (Kawamata et al. 1996, Muthuraman et al. 2008a, Jagodic et al. 2008). Calcium influx through different neuronal calcium channels including L-, and T-type, plays a fundamental role in excitationtranscription coupling, triggering changes in gene expression and potentiating the phosphorylation of the ERK1/2 MAP kinases, the p38 MAPK, or the CaM kinase II to activate the CRE/CREB-dependent transcription (Dolmetsch et al. 2001, West et al. 2001). The activation of the CREB transcription factor contributes to long-term modifications in the processing of nociceptive information in the spinal cord (Song et al. 2005, Crown et al. 2006). Activation of these signalling pathways in the dorsal horn participates in pain hypersensitivity (Kawasaki et al. 2004, Song et al. 2005). Treatment with Ocimum sanctum and its saponin rich fraction, attenuated the chronic constriction injury associated increase in oxidative stress and calcium levels. Ocimum sanctum has a well documented antioxidant effect (Yanpallewar et al. 2004, George and Chaturvedi 2008) and also decreases the calcium levels (Muthuraman et al. 2008b).

The increase in free radical during neuropathic pain may be attributed to the rise in intracellular calcium levels. Although the precise mechanisms are unknown, it may be speculated that increased release of glutamate during neuropathic pain. 
may increase intracellular $\mathrm{Ca}^{2+}$ (Sekiguchi and Kawabata), which may contribute in activating NADPH oxidase to generate free radicals (Abramov et al. 2007). Furthermore, calcium may potentiate oxygen free radical injury to mitochondria, and $\mathrm{Ca}^{2+}$ induced potentiation of oxygen free radical injury has been linked to activation of phospholipase A2 (Malis and Bonventre 1986). On the other hand, free radicals have also been well documented to increase calcium levels (Doan et al. 1994, Kawakami and Okabe 1998). Free radicals may increase calcium ionic homeostasis due to alteration in membrane phospholipids leading to an increase in membrane permeability (Burton et al. 1990). Therefore, it may possible that free radicals and calcium may induce a vicious cycle to increase the levels of each other, which may contribute in producing neuropathic pain.

Based on above findings, it may be proposed that Ocimum sanctum reduces calcium levels indirectly due to decreased free radical generation. However, it may also be possible that direct action of Ocimum sanctum is responsible for the observed decrease in the calcium levels. Therefore, the observed decrease in calcium levels due to Ocimum sanctum may be due to either direct action or secondary to decrease in oxidative stress. However, data of the present study is still insufficient to elaborate the precise mechanism of Ocimum sanctum mediated decrease in calcium levels. Furthermore, saponins have also been reported to decrease oxidative stress (Feresin et al. 2002) and calcium levels (Tao et al. 2005, Li et al. 2009 a, b).

Based on above findings, it may be proposed that Ocimum sanctum has potential in ameliorating the painful symptoms in chronic constriction injury-induced peripheral neuropathy, and saponins may be the main chemical class responsible for its beneficial effect in neuropathic pain. Furthermore, the pain relieving effects of Ocimum sanctum and its saponin rich fraction may be due to attenuation of nerve injury inciting agent-induced increased levels of calcium and free radicals.

\section{CONCLUSION}

Ocimum sanctum has ameliorative potential in attenuating painful neuropathic state, which may be attributed to a decrease in oxidative stress and calcium levels. Furthermore, saponin rich fraction of Ocimum sanctum may be responsible for its noted beneficial effect in neuropathic pain in rats.

\section{ACKNOWLEDGMENTS}

The authors are grateful to Department of Pharmaceutical Sciences and Drug Research, Punjabi University, Patiala, India for supporting this study and providing technical facilities for the work.

\section{RESUMO}

$\mathrm{O}$ presente estudo foi delineado para avaliar-se o potencial efeito analgésico de extratos de Ocimum sanctum e uma fração enriquecida em saponinas na dor neuropática induzida pela lesão por constrição crônica de nervos periféricos em ratos. A lesão foi induzida pela colocação de quatro ligaduras apostas ao nervo ciático, proximalmente à sua trifurcação. Hiperalgesia mecânica, alodínia ao frio, hiperalgesia ao calor nas patas e hiperalgesia ao frio na cauda foram determinadas usando-se testes de picada de agulha, exposição à acetona, placa quente e teste de imersão em solução gelada, respectivamente. Análises bioquímicas com conteúdo de espécies reativas ao tiobarburato em tecidos e conteúdo de ânion superóxido (ambos marcadores de estresse oxidativo) e os níveis totais de cálcio foram realizadas. A lesão por constrição crônica do nervo ciático foi acompanhada de desenvolvimento de hiperalgesia mecânica, alodínia ao frio, hiperalgesia ao calor e ao frio, acompanhadas de aumento de marcadores de estresse oxidativo e níveis de cálcio. A administração de extratos de Ocimum sanctum (100 e $200 \mathrm{mg} / \mathrm{kg}$, via oral) e sua fração enriquecida em saponinas $(100$ e $200 \mathrm{mg} / \mathrm{kg}$, via oral) por 14 dias atenuou significativamente a dor neuropática associada à constrição crônica do nervo ciático, bem como associou-se à diminuição de estresse oxidativo e níveis de cálcio. Conclui-se que a fração 
enriquecida em saponinas de Ocimum sanctum tem potencial atenuante da dor neuropática, que poderia ser atribuída à diminuição do estresse oxidativo e níveis teciduais de cálcio.

Palavras-chave: lesão por constrição crônica, Ocimum sanctum, saponinas, cálcio, estresse oxidativo.

\section{REFERENCES}

ABRAMOV AY, SCORZIELlo A AND DUChEN MR. 2007. Three distinct mechanisms generate oxygenfree radicals in neurons and contribute to cell death during anoxia and reoxygenation. J Neurosci 27:1129-1138.

AHMAD A ET AL. 2012. Ocimum sanctum attenuates oxidative damage and neurological deficits following focal cerebral ischemia/reperfusion injury in rats. Neurol Sci 33: 1239-1247.

AL-HABORI M AND RAMAN A. 1998. Antidiabetic and hypocholesterolaemic effects of fenugreek. Phytother Res 12: 233-242.

Arguis MJ, Perez J, Martínez G, Ubre M and Gomar C. 2008. Contralateral neuropathic pain following a surgical model of unilateral nerve injury in rats. Reg Anesth Pain Med 33(3): 211-216.

BALIGA MS, JimMY R, THILAKCHAND KR, SUNITHA V, BHAT NR, Saldanha E, Rao S, Rao P, ARora R and Palatty PL. 2013. Ocimum sanctum L (Holy Basil or Tulsi) and its phytochemicals in the prevention and treatment of cancer. Nutr Cancer. 65(Suppl. 1): 26-35.

BENNETT GJ AND XIE YK. 1988. A peripheral mononeuropathy in rat that produces disorders of pain sensation like those seen in man. Pain 33: 87-107.

BHATTACHARYyA D, SUR TK, JANA U AND DEBNATH PK. 2008. Controlled programmed trial of Ocimum sanctum leaf on generalized anxiety disorders. Nepal Med Coll J 10(3): 176-179.

Burton KP, MORRIS AC, MASSEY KD, BUJA LM AND HAGLER HK. 1990. Free radicals alter ionic calcium levels and membrane phospholipids in cultured rat ventricular myocytes. J Mol Cell Cardiol 22: 1035-1047.

Chen ZH, Li J, LIU J, ZHAO Y, ZHANG P, ZHANG MX AND Zhang L. 2008. Saponins isolated from the root of Panax notoginseng showed significant anti-diabetic effects in KK-Ay mice. Am J Chin Med 36(5): 939-951.

Crown ED, Ye Z, Johnson KM, Xu GY, McAdoo DJ AND HuLSEBOSCH CE. 2006. Increases in the activated forms of ERK 1/2, p38 MAPK, and CREB are correlated with the expression of at level mechanical allodynia following spinal cord injury. Exp Neurol 199: 397-407.

DE AlmeIdA I, AlVIANO DS, VIEIRA DP, ALVEs PB, BLANK AF, LOPES AH, ALVIANO CS AND RosA MS. 2007. Antigiardial activity of Ocimum basilicum essential oil. Parasitol Res 101: 443-452.

DeCOSTERD I AND WoOlF CJ. 2000. Spared nerve injury: an animal model of persistent peripheral neuropathic pain. Pain 87: 149-158.
DoAn TN, Gentry DL, Tylor AA AND ElliotT SJ. 1994. Hydrogen peroxide activates agonist-sensitive $\mathrm{Ca}^{2+}$ influx pathways in canine venous endothelial cells. Biochem J 297: 209-215.

Dolmetsch RE, Pajvani U, Fife K, SPOtTs JM And GREENBERG ME. 2001. Signaling to the nucleus by an L-type calcium channel-calmodulin complex through the MAP kinase pathway. Science 294: 333-339.

DowdALl T, RoBInson I AND MEERT TF. 2005. Comparison of five different rat models of peripheral nerve injury. Pharmacol Biochem Behav 80(1): 93-108.

EBATA N, NAKAJIMA K, HAYASHI K, OKADA M AND MARUNO M. 1996. Saponins from the root of Bupleurum falcatum. Phytochemistry 41(3): 895-901.

EDDY NB AND LEIMBACH D. 1953. Synthetic analgesics. II. Dithienylbutenyl- and ithienylbutylamines. J Pharmacol Exp Ther 107 (3): 385-393.

ERICHSEN HK AND BlackBuRN-MunRo G. 2002. Pharmacological characterization of the spared nerve injury model of neuropathic pain. Pain 98: 151-161.

Feresin GE, TApia A, Gutierrez RA, Delporte C, BACKHOUSE ERAZO $\mathrm{N}$ and SCHMEDA-HIRSCHMANN G. 2002. Free radical scavengers, anti-inflammatory and analgesic activity of Acaena magellanica. J Pharm Pharmacol 54(6): 835-844.

George S And Chaturvedi P. 2008. Protective role of Ocimum canum plant extract in alcohol-induced oxidative stress in albino rats. Br J Biomed Sci 65(2): 80-85.

JAGGI AS, JAIN V AND SINGH N. 2011. Animal models of neuropathic pain. Fundam Clin pharmacol 25: 1-28.

JAGGI AS AND SINGH N. 2011. Exploring the potential of telmisartan in chronic constriction injury-induced neuropathic pain in rats. Eur J Pharmacol 667: 215-221.

JAGGI RK, MADAAN R AND SINGH B. 2003. Anticonvulsant potential of holy basil, Ocimum sanctum Linn., and its cultures. Indian J Exp Biol 41: 1329-1333.

JAGODIC MM, PATHIRATHNA S, JOKSOVIC PM, LEE W, NELSON MT, NAIK AK, SU P, JEVTOVIC-TODOROVIC V AND TODOROVIC SM. 2008. Up-regulation of the T-type calcium current in small rat sensory neurons after chronic constrictive injury of the sciatic nerve. J Neurophysiol 99(6): 3151-3156.

JAIN V, JAGGI AS AND SINGH N. 2009. Ameliorative potential of rosiglitazone in tibial and sural nerve transection-induced painful neuropathy in rats. Pharmacol Res 59(6): 385-392.

KAUR G, JAGGI AS AND SINGH N. 2010. Exploring the potential effect of Ocimum sanctum in vincristine-induced neuropathic pain in rats. J Brachial Plex Peripher Nerve Inj 5: 3 .

KAWAKAMI M AND OKABE E. 1998. Superoxide Anion RadicalTriggered $\mathrm{Ca}^{2+}$ Release from Cardiac Sarcoplasmic Reticulum through Ryanodine Receptor $\mathrm{Ca}^{2+}$ Channel. Mol Pharmacol 53: 497-503.

KAWAMATA M AND OMOTE K. 1996. Involvement of increased excitatory amino acids and intracellular $\mathrm{Ca}^{2+}$ concentration in the spinal dorsal horn in an animal model of neuropathic pain. Pain 68: 85-96. 
KAWASAKI Y, KOHNO T, ZHUANG ZY, BRENNER GJ, WANG H, VAN DER MEer C, BeFORT K, WOOLF CJ AND Ji RR. 2004 Ionotropic and metabotropic receptors, protein kinase $\mathrm{A}$, protein kinase $\mathrm{C}$, and $\mathrm{Src}$ contribute to $\mathrm{C}$-fiberinduced ERK activation and cAMP response element-binding protein phosphorylation in dorsal horn neurons, leading to central sensitization. J Neurosci 24: 8310-8321.

KHALIL Z, LiU T AND HELME RD. 1999. Free radicals contribute to the reduction in peripheral vascular responses and the maintenance of thermal hyperalgesia in rats with chronic constriction injury. Pain 79: 31-37.

Kim HK, Park SK, Zhou JL, Taglialatela G, Chung K, CogGeShall RE AND CHUng JM. 2004. Reactive oxygen species (ROS) play an important role in a rat model of neuropathic pain. Pain 111: 116-124.

KIM JH ET AL. 2005. Protective effects of ginseng saponins on 3-nitropropionic acid-induced striatal degeneration in rats. Neuropharmacology 48(5): 743-756.

KLEINSChNitz C, HofstetTER HH, MeUth SG, BRAUNINGER S, SOMMER G AND STOLl G. 2006. T cell infiltration after chronic constriction injury of mouse sciatic nerve is associated with interleukin-17 expression. Exp Neurol 200: 480-485.

KLUSÁKOVÁ I AND DuBOVÝ P. 2009. Experimental models of peripheral neuropathic pain based on traumatic nerve injuries - An anatomical perspective. Ann Anat 191: 248-259.

Koltzenburg M, Wall PD AND McMahon SB. 1999. Does the right side know what the left is doing? Trends Neurosci 22: 122-127.

Li W, Li W, Yin Y, Gong H, Wu G AND ZHU F. 2009b. Protective effects of AST and ASI on memory impairment and its mechanism in senescent rats treated by GC. Zhongguo Zhong Yao Za Zhi 34(2): 199-203.

LI Y, CHEN X, LIU H, LUO F AND LI G. 2009a. Effects of ginseng total saponins with berberine on plasma brain natriuretic peptide and $\mathrm{Ca}^{2+}$ concentration in experimental rats with chronic congestive heart failure. Zhongguo Zhong Yao Za Zhi 34(3): 324-327.

LIU J, Li Y, YUAN X, YANG Z AND LIN Z. 2008. Sodium betaaescin may be an effective therapeutic agent for Bell's palsy. Med Hypotheses 71(5): 762-764.

LOWRY OH, ROSENBROUGH NJ, FARR AL AND RANDALL RJ. 1951. Protein measurement with folin phenol reagent. J Biol Chem 193: 265-275.

LU J, ZHENG YL, Wu DM, LUO L, SUn DX AND SHAN Q. 2007. Ursolic acid ameliorates cognition deficits and attenuates oxidative damage in the brain of senescent mice induced by D-galactose. Biochem Pharmacol 74(7): 1078-1090.

MALIS CD AND BONVENTRE JV. 1986. Mechanism of calcium potentiation of oxygen free radical injury to renal mitochondria. A model for post-ischemic and toxic mitochondrial damage. J Biol Chem 261: 14201-14218.

MANU KAAND KUTTAN G. 2008. Ursolic acid induces apoptosis by activating p53 and caspase-3 gene expressions and suppressing NF-kappaB mediated activation of bcl-2 in B16F-10 melanoma cells. Int Immunopharmacol 8(7): 974-981.
Merskey H AND BogduK N (Eds). 1994. Classification of Chronic Pain: Descriptions of Chronic Pain Syndromes and Definitions of Pain Terms. $2^{\text {nd }}$ ed., Seattle, Wash: IASP Press; 1994.

MiKA J, KOROSTYNSKI M, KAMINSKA D, WAWRZCZAKBargiela A, OSIKowicz M, MaKuCh W, PERZEWLOCKI R AND PERZEWLOCKA B. 2008. Interleukin-1alpha has antiallodynic and antihyperalgesic activities in a rat neuropathic pain model. Pain 138(3): 587-597.

MiKa J, OsIKowicz M, MaKUCH W AND PRZEWlocka B. 2007. Minocycline and pentoxifylline attenuate allodynia and hyperalgesia and potentiate the effects of morphine in rat and mouse models of neuropathic pain. Eur $\mathrm{J}$ Pharmacol 560: 142-149.

Mika J, WaWrZCZaK-BARgIEla A, OSIKOWICZ M, MAKUCH W AND PRZEWLOCKA B. 2009. Attenuation of morphine tolerance by minocycline and pentoxifylline in naive and neuropathic mice. Brain Behav Immun 23(1): 75-84.

Moharram FA AND EL-ShENAWY SM. 2007. Antinociceptive and anti-inflammatory steroidal saponins from Dracaena ombet. Planta Med 73(10): 1101-1106.

Morin N, OWOlabi SA, Harty MW, Papa EF, Tracy Jr TF, SHAW SK, KIM M AND SAAB CY. 2007. Neutrophils invade lumbar dorsal root ganglia after a chronic constriction injury of the sciatic nerve. J Neuroimmunol 184: 164-171.

Muthuraman A, Diwan V, JagGi AS, Singh N AND Singh D. 2008b. Ameliorative effects of Ocimum sanctum in sciatic nerve transection-induced neuropathy in rats. J Ethnopharmacol 120(1): 56-62.

Muthuraman A, JaGgi AS, Singh N AND Singh D. 2008a. Ameliorative effects of amiloride and pralidoxime in chronic constriction injury and vincristine-induced painful neuropathy in rats. Eur J Pharmacol 587: 104-111.

NAKAMURA S AND ATSUTA Y. 2006. The effects of experimental neurolysis on ectopic firing in a rat chronic constriction injury model. Hand Surg Am 31: 35-39.

NECKER R AND HELlON RF. 1978. Noxious thermal input from the rat tail: modulation by descending inhibitory influences. Pain 4: 231-242.

OKHAWA H, OHISHI N AND YaGi K. 1979. Assay for lipid peroxidation in animal tissue by thiobarbituric acid reaction. Anal Biochem 95: 351-358.

PAL D, SAHOO M AND Mishra AK. 2005. Analgesic and anticonvulsant effects of Saponin isolated from the stems of Opunntia vulgaris mill. in mice. Eur Bull Drug Res 13: 91-97.

Rhiouani H, SETtaf A, Lyoussi B, Cherrah Y, LACAILleDUBOIS MA AND HASSAR M. 1999. Effects of saponins from Herniaria glabra on blood pressure and renal function in spontaneously hypertensive rats. Therapie 54(6): 735-739.

SADRAEI H, ASGHARI G AND HeKMATTI AA. 2003 Antispasmodic effect of three fractions of hydroalcoholic extract of Pycnocycla spinosa. J Ethnopharmacol 86(2-3): $187-190$

SeKiguCHI F AND KaWABATA A. 2013. T-type calcium channels: functional regulation and implication in pain signaling. J Pharmacol Sci 122: 244-250. 
Senthil S, Chandramohan G and Pugalendi KV. 2007. Isomers (oleanolic and ursolic acids) differ in their protective effect against isoproterenol-induced myocardial ischemia in rats. Int J Cardiol 119(1): 131-133.

SeVEringhaus JW AND FerRebeE JW. 1950. Calcium determination by flame photometry; methods for serum, urine, and other fluids. J Biol Chem 187: 621-630.

ShiBATA S. 2001. Chemistry and Cancer Preventing Activities of Ginseng Saponins and Some Related Triterpenoid Compounds. J Korean Med Sci 16: 28-37.

SOMOVA LO, NADAR A, RAMmanan P AND SHODE FO. 2003. Cardiovascular, antihyperlipidemic and antioxidant effects of oleanolic and ursolic acids in experimental hypertension. Phytomedicine 10(2-3): 115-121.

Song XS, CAO JL, Xu YB, He JH, Zhang LC AND Zeng YM. 2005. Activation of ERK/CREB pathway in spinal cord contributes to chronic constrictive injury-induced neuropathic pain in rats. Acta Pharmacol Sin 26:789-798.

SotgiU ML, Biella G AND Riva L. 1994. A study of early ongoing activity in dorsal horn units following sciatic nerve constriction. Neuroreport 5: 2609-2612.

TAN EC, BAHrami S, Kozlov AV, KuRVERs HA, TER LaAK HJ, NOHL H, REDL H AND GORIS RJ. 2009. The Oxidative Response in the Chronic Constriction Injury Model of Neuropathic Pain. J Surg Res 152: 84-88.

TAO J, WANG H, Zhou H AND Li S. 2005. The saponin monomer of dwarf lilyturf tuber, DT-13, reduces L-type calcium currents during hypoxia in adult rat ventricular myocytes. Life Sci 77(24): 3021-3030.

Venuprasad MP, Hemanth Kumar K AND Khanum F. 2013. Neuroprotective effects of ydroalcoholic extract of Ocimum sanctum against $\mathrm{H} 2 \mathrm{O} 2$ induced neuronal cell damage in SH-SY5Y cells via its antioxidative defence mechanism. Neurochem Res 38: 2190-2200.
Wang HD, Pagano PJ, Du Y, CAYATte AJ, QuinN MT, BRECHER P AND COHEN RA. 1998. Superoxide anion from the adventitia of the rat thoracic aorta inactivates nitric oxide. Circ Res 82: 810-818.

WANG J, ZHOU H, JiANG Z, WONG Y AND LiU L. 2008. In Vivo Anti-inflammatory and Analgesic Activities of a Purified Saponin Fraction Derived from the Root of Ilex pubescens. Biol Phar Bull 31(4): 643-650.

WANG LC, WANG B, NG SY AND LEE TF. 2006. Effects of ginseng saponins on beta-amyloid-induced amnesia in rats. J Ethnopharmacol 103(1): 103-108.

West AE, Chen WG, Dalva MB, Dolmetsch RE, Kornhauser JM, Shaywitz AJ and TAKasu MA, TAO X And GreEnberg ME. 2001. Calcium regulation of neuronal gene expression. Proc Natl Acad Sci USA 98: 11024-11031.

WoOlF CJ AND MANNION RJ. 1999. Neuropathic pain, aetiology, symptoms, mechanisms and management. Lancet 353: 1959-1964.

YANPALlEWAR SU, SUNITA R, MOHAN K AND ACHARYA SB. 2004. Evaluation of antioxidant and neuroprotective effect of Ocimum sanctum on transient cerebral ischemia and long-term cerebral hypoperfusion. Pharmacol Biochem Behav 79: 155-164.

Yin X, Zhang Y, Wu H, Zhu X, Zheng X, JiAng S, Zhuo H, Shen J, LI L AND QIU J. 2004. Protective effects of Astragalus saponin I on early stage of diabetic nephropathy in rats. J Pharmacol Sci 95(2): 256-266.

ZEINAB K AND BEREHA K. 2001. A role for free radicals and nitric oxide in delayed recovery in aged rats with chronic constriction nerve injury. Free Radic Biol Med 31: 430-439. 
